\title{
Determination of ceruloplasmin, some other acute phase proteins, and biochemical parameters in cows with endometritis
}

\author{
S. Kaya ${ }^{1}$, O. Merhan ${ }^{2}$, C. Kacar ${ }^{1}$, A. Colak ${ }^{3}$ and K. Bozukluhan ${ }^{4}$ \\ 1. Department of Obstetrics and Gynecology, Faculty of Veterinary Medicine, University of Kafkas, Kars, Turkey; \\ 2. Department of Biochemistry, Faculty of Veterinary Medicine, University of Kafkas, Kars, Turkey; 3. Department of \\ Obstetrics and Gynecology, Faculty of Veterinary Medicine, University of Ataturk, Erzurum, Turkey; 4. Department of \\ Veterinary Health, Kars School of Higher Vocational Education, University of Kafkas, Kars, Turkey. \\ Corresponding author: S. Kaya, e-mail: semra-kafkas@hotmail.com, \\ OM: oguzmerhan@hotmail.com, CK: cihan3000@hotmail.com, AC: fgacolak@hotmail.com, \\ KB: kbozukluhan@hotmail.com \\ Received: 26-05-2016, Accepted: 22-08-2016, Published online: 08-10-2016
}

doi: 10.14202/vetworld.2016.1056-1062 How to cite this article: Kaya S, Merhan O, Kacar C, Colak A, Bozukluhan K (2016) Determination of ceruloplasmin, some other acute phase proteins, and biochemical parameters in cows with endometritis, Veterinary World, 9(10): 1056-1062.

\begin{abstract}
Aim: The aim of this study is to determine serum ceruloplasmin levels in cows with endometritis of varying degrees of severity and to establish whether or not there is a correlation between acute phase protein (APP) levels and biochemical parameters.

Material and Methods: The study was conducted with 100 Brown Swiss cows (3-8 years of age) on days 28-32 postpartum. Cows were divided into endometritis (mild, moderate, and severe endometriosis) and healthy groups based on ultrasonography, vaginoscopy, and cytological examination. Blood samples were collected from all cows. Levels of haptoglobin (Hp), serum amyloid A (SAA), ceruloplasmin, albumin, and some biochemical parameters were analyzed.

Results: Hp, SAA, and ceruloplasmin levels were higher in cows with endometritis than in healthy cows ( $p=0.001$ ), and the levels of these APPs increased as endometritis became more severe $(\mathrm{p}=0.001)$. Some significant correlations were found between APPs and the biochemical parameters that were analyzed. In conclusion, it was determined that ceruloplasmin levels increase significantly in the presence of endometritis and proportionate to the severity of endometritis. A significant correlation was found between ceruloplasmin levels and Hp and SAA levels.
\end{abstract}

Conclusion: It was concluded that ceruloplasmin levels can be used in the diagnosis of endometritis as an alternative to Hp and SAA levels.

Keywords: albumin, ceruloplasmin, cow, endometritis, haptoglobin, serum amyloid A.

\section{Introduction}

Acute phase proteins (APPs) are blood proteins synthesized by hepatocytes as part of the innate immune system's response to various stimuli such as inflammation, trauma, and infection [1]. The main function of APPs is to assist in defending the host against pathological damage and to restore homeostasis [2]. The levels of positive APPs (haptoglobin [Hp], serum amyloid A [SAA], ceruloplasmin, C-reactive protein, etc.) increase in response to infection, whereas the production of negative APPs (prealbumin, albumin, transferrin, etc.) is suppressed $[1,3]$. APPs are used in the early and accurate detection of infections in ruminants [4]. The main APPs used to detect genital tract infections and to determine treatment efficacy are Hp, SAA, and albumin [5-8]. Ceruloplasmin is a plasma $\alpha-2$ glycoprotein. It is an enzyme that plays an

Copyright: Kaya, et al. Open Access. This article is distributed under the terms of the Creative Commons Attribution 4.0 International License (http://creativecommons.org/licenses/by/4.0/), which permits unrestricted use, distribution, and reproduction in any medium, provided you give appropriate credit to the original author(s) and the source, provide a link to the Creative Commons license, and indicate if changes were made. The Creative Commons Public Domain Dedication waiver (http://creativecommons.org/ publicdomain/zero/1.0/) applies to the data made available in this article, unless otherwise stated. important role in copper transport in the blood stream (95\% of copper in animals) and iron metabolism (ferroxidase) $[9,10]$. Copper improves immune function by acting on the levels of various enzymes mediating the antioxidant system. Ceruloplasmin mediates the transport of copper by the enzymes lysyl oxidase and $\mathrm{Cu}-\mathrm{Zn}$ superoxide dismutase, which play a role in tissue repair, and it plays a role in the antioxidant system. It also protects cells against oxidative damage. Phagocytosis and antimicrobial activity decrease if serum ceruloplasmin levels fall. As a result, the need for this enzyme increases in inflammatory conditions [11].

The start of lactation in the postpartum period increases the energy requirement. Body reserves are used to overcome the energy insufficiency caused by the negative energy balance $[12,13]$. The resulting metabolic stress causes impairment of other body functions [14]. It damages liver cells and alters some liver enzyme functions (aspartate aminotransferase [AST] and alkaline phosphatase [ALP]) $[15,16]$. One of the methods for detecting energy insufficiency is to determine the circulating urea concentration [17]. Although it is known that there is a significant relation between endometritis and APPs and metabolic 
parameters, no study investigating that the relation between the severity of endometritis and these parameters was found.

This study had two objectives. The first was to determine whether or not ceruloplasmin levels can be used as an indicator in the diagnosis of endometritis. The second was to determine changes in the levels of certain APPs and biochemical parameters according to the severity of endometritis and to establish whether or not, there is a correlation between them.

\section{Material and Methods \\ Ethical approval}

This study was conducted after obtaining approval from the Kafkas University Animal Experiments Local Ethics Committee (KAÜ HADYEK - Submission: 2016/028).

\section{Animals}

This study was conducted on Brown Swiss cows (3-8 years of age) at the Kafkas University Veterinary School Research and Application Farm, which were fed on meadow grass, silage (live weight $\times 1.5 / 100$ ), and dairy cattle feed $(20 \%$ crude protein, 2700 energy).

\section{Classifications and determination of endometritis}

Cows that were monitored immediately after parturition $(n=140)$ but found to have retention secundarium, vaginal tears, mastitis, and foot problems during early postpartum examinations $(n=20)$ were excluded. Examinations to diagnose endometritis were carried out between days 28-32 postpartum. The vulva and the perineum were examined for the presence of discharge, and then a vaginoscopy was performed. The severity of endometritis in cows with discharge on the vaginal wall or the cervix uteri was recorded according to the discharge score as described by Williams et al. [18]. In cows that showed no evidence of discharge, the diameters of the cornua, the presence of fluid in the uterine lumen, and diameters of the cervix uteri were measured by ultrasonography $(7.5 \mathrm{MHz}$, $\operatorname{Titan}^{\circledR}$, Sonosite, USA). Category of endometritis was modified and classified by ultrasonographic examination which was described by Kasimanickam et al. [19] and Mari et al. [20]. Animals with an uterine discharge containing mostly translucent mucus with a small amount of pus flakes or an anechoic line in the lumen, diameter of cervix uteri $<5 \mathrm{~cm}$ were allocated to mild endometritis (ME) group. Animals with discharge containing yellow or white flakes of pus at a percentage $<50 \%$ or an anechoic fluid, mucosa with irregular edges, and diameter of cervix uteri $5-7.5 \mathrm{~cm}$ were allocated to moderate endometritis group (E). Animals displaying cervix and a uterine discharge containing more than $50 \%$ of yellow- and white-colored flakes of pus, occasionally sanguineous or an enlarged lumen, echogenic fluid, and diameter of cervix uteri $>7.5 \mathrm{~cm}$ were assigned to severity endometritis (SE) group. Endometrial samples were collected from cows $(n=50)$ that appeared to be healthy in clinical examinations using the cytobrush technique. The vulva was cleaned with a paper towel, and plastic sheaths were used to prevent contamination of the cytobrush in the vagina. Endometrial samples were obtained by rotating cytobrushes a few times on the uterine endometrium. The samples were smeared on slides and dried. They were stained with Giemsa solution (Merck ${ }^{\circledR}$, Turkey). Then, the neutrophil to leukocyte ratio was calculated using microscopy (Olympus CX23, Olympus Corp, Japan) (counting a minimum of 100 cells at $400 \times$ magnification). Cows with the neutrophil to epithelial cell ratio $>18 \%$ were considered to have subclinical endometritis [19]. Body condition scores (BCS) were assessed immediately after the examinations as described by Edmonson et al. [21] (1=thin; 5=fat; in increments of $0.25)$.

\section{Assessment of blood samples}

Blood samples were collected from the vena coccygea of all animals into vacuum gel serum tubes. The samples were centrifuged at $1200 \mathrm{~g}$ for $10 \mathrm{~min}$. The serums were then transferred to Eppendorf tubes and stored at $-20^{\circ} \mathrm{C}$ until analysis. Hp levels were determined using the method described by Skinner et al. [22], and ceruloplasmin levels using the method described by Colombo and Richterich [23] (UV1201, Shimadzu, Japan). SAA levels were determined using the ELISA kit (Tridelta Development Limited, Ireland). Albumin, AST, ALP, urea, creatinine, and total protein (TP) levels were determined colorimetrically $\left(\right.$ Epoch $^{\circledR}$, Biotek, USA) using the commercial test kit (DDS, Turkey).

\section{Statistical analysis}

Statistical analyses were performed using the SPSS $^{\circledR}$ (SPSS 18, IL, USA) software program. Hp, SAA, ceruloplasmin, albumin, AST, ALP, urea, creatinine, and TP levels in each group were tested for normality using the Shapiro-Wilk test. Differences in BCS, age, SAA, ceruloplasmin, albumin, AST and ALP levels between the groups were compared using ANOVA and Tukey HSD tests. Hp, urea, creatinine, and TP levels were compared using the KruskalWallis test, and differences were recorded. Then, the groups were subjected to the Mann-Whitney test; the correlations between $\mathrm{Hp}, \mathrm{SAA}$, ceruloplasmin, albumin, and biochemical parameters were compared using the Pearson correlation test. APP levels in cows classified according to BCS and parity were compared using the Mann-Whitney test. The results were expressed as mean \pm standard error, and values $\leq 0.05$ were considered significant. Selection of cutoff points for $\mathrm{Hp}$, SAA, and ceruloplasmin was undertaken using receiver operating characteristic curve (ROC) analysis. ROC analysis provides determining plots a curve of sensitivity versus specificity for all possible threshold values of the parameters. The area under the curve used to measure the diagnostic accuracy of the examined parameters [24]. 


\section{Results}

Postpartum examinations results and distribution of the groups by body condition score and age

Based on the vaginal discharge scores and the results of the ultrasonography, $\mathrm{ME}$ was diagnosed in 30 cows, $\mathrm{E}$ in 20 cows, and SE in 20 cows. 45 out of 50 cows that were examined cytologically were considered healthy. However, data from only 30 healthy cows were used in the analyses. BCS were similar in healthy cows $(2.62 \pm 0.09)$ and cows with endometritis $(\mathrm{ME}=2.73 \pm 0.08, \mathrm{E}=2.60 \pm 0.14$, and $\mathrm{SE}=2.61 \pm 0.09)$, and no statistically significant difference was found $(\mathrm{p}>0.05)$. No significant difference was found in distribution of the groups (healthy $=3.76 \pm 0.24, \mathrm{ME}=4.03 \pm 0.16$, $\mathrm{E}=4.6 \pm 0.44$, and $\mathrm{SE}=3.9 \pm 0.23)$ by mean age $(\mathrm{p}>0.05)$.

The levels of APPs (Hp, SAA, ceruloplasmin, and albumin) in groups

Hp, SAA, ceruloplasmin, and albumin levels in the groups are presented in Figure-1. In cows with endometritis, serum $\mathrm{Hp}(\mathrm{ME}=154 \pm 5.16, \mathrm{E}=183 \pm 6.2$, and $\mathrm{SE}=234 \pm 10.7 \mu \mathrm{g} / \mathrm{ml}), \mathrm{SAA}(\mathrm{ME}=20.25 \pm 0.65$, $\mathrm{E}=28.17 \pm 1.22$, and $\mathrm{SE}=34.62 \pm 1.28 \mu \mathrm{g} / \mathrm{ml}$ ), and ceruloplasmin levels $(\mathrm{ME}=18.57 \pm 0.36, \mathrm{E}=22.14 \pm 0.75$, and $\mathrm{SE}=27.64 \pm 0.87 \mathrm{mg} / \mathrm{dl})$ were significantly higher than in healthy cows $(72 \pm 2.76 \mu \mathrm{g} / \mathrm{ml}, 14.24 \pm 0.52 \mu \mathrm{g} / \mathrm{ml}$, and $13.52 \pm 0.32 \mathrm{mg} / \mathrm{dl}$, respectively) $(\mathrm{p}=0.001)$. Levels of albumin, which is considered a negative APP, were similar in the groups ( $\mathrm{p}>0.05)$ (Figure-1).

Cutoff, sensitivity, and specificity values for the $\mathrm{Hp}$, SAA, and ceruloplasmin levels determined as a result of the ROC analysis on healthy cows and those with endometritis (mild and moderate) are provided in Table-1. Hp, SAA, and ceruloplasmin levels did not overlap in healthy cows and those with severe endometritis. Therefore, the cutoff values were not calculated for these two groups (Table-1).

The levels of some biochemical parameters (AST, ALP, urea, creatinine, and TP) in the groups

Aspartate aminotransferase, ALP, urea, creatinine, and TP levels are presented in Table-2. In cows

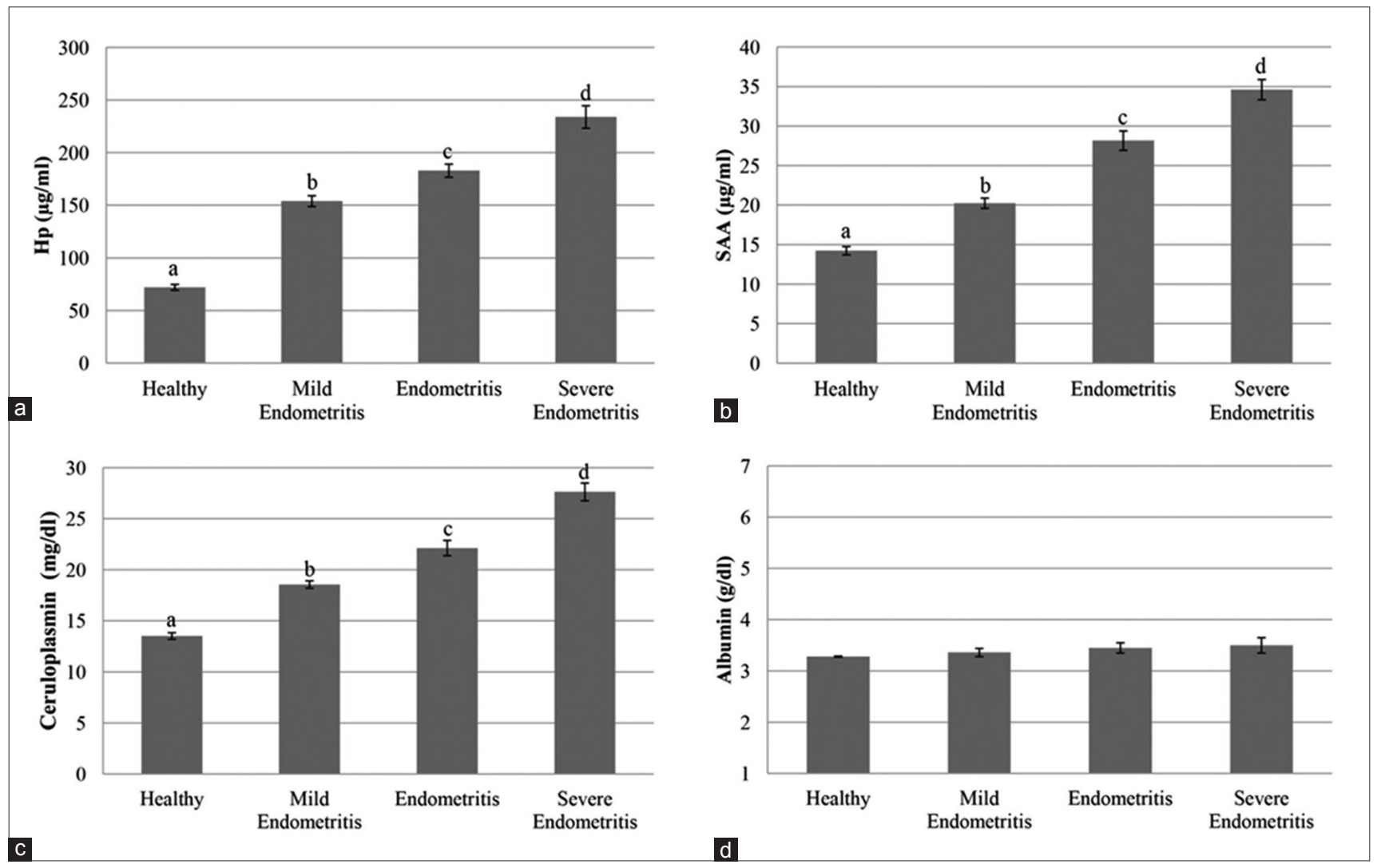

Figure-1: (a-d) Comparison of acute phase protein levels between groups (a:b:c:d: 0.001).

Table-1: Determination of threshold values in healthy cows and those with endometritis (mild and moderate) using ROC analysis.

\begin{tabular}{llcccr}
\hline Variables & Groups & Cutoff & AUC* & Sensitivity (\%) & Specificity (\%) \\
\hline $\mathrm{Hp}(\mu \mathrm{g} / \mathrm{ml})$ & Healthy-ME & 85 & 0.813 & 0.95 & 0.575 \\
$\mathrm{SAA}(\mu \mathrm{g} / \mathrm{ml})$ & Healthy-ME & 16.25 & 0.85 & 0.95 & 0.55 \\
& Healthy-E & 19.275 & 0.993 & 0.95 & 0.67 \\
$\mathrm{Cp}(\mathrm{mg} / \mathrm{dl})$ & Healthy-ME & 14.64 & 0.983 & 0.967 & 0.7 \\
& Healthy-E & 16.55 & 0.998 & 0.95 & 0.967
\end{tabular}

$\mathrm{AUC}=$ Area under the curve, $\mathrm{Hp}=$ Haptoglobin, $\mathrm{SAA}=$ Serum Amyloid $\mathrm{A}, \mathrm{Cp}=$ Ceruloplasmin, $\mathrm{ME}=$ Mild endometritis, $\mathrm{E}=$ Moderate endometritis, $* A \cup C$ were different from $A \cup C=0.5$ in all variables, $R O C=$ Receiver operator characteristic curve 
with endometritis, serum AST levels (ME $=65.82 \pm 2.02$, $\mathrm{E}=92.27 \pm 5.40$, and $\mathrm{SE}=108.37 \pm 3.52 \mathrm{U} / \mathrm{L}$ ) were significantly higher than in healthy cows $(58.64 \pm 1.41$ $\mathrm{U} / \mathrm{L} ; \mathrm{p}=0.001$ ). Similarly, serum ALP levels were higher in cows with endometritis than in healthy cows $(38.69 \pm 1.77 \mathrm{U} / \mathrm{L})$, and the serum ALP level increased as endometritis became more severe. The highest serum ALP levels were seen in cows with severe endometritis $(68.52 \pm 3.49 \mathrm{U} / \mathrm{L})$. Urea and creatinine levels were significantly higher in cows with endometritis than in healthy controls. TP levels in healthy cows and cows with mild and moderate endometritis were similar ( $p>0.05)$, whereas they were significantly higher in cows with severe endometritis than in healthy cows $(\mathrm{p}=0.01)($ Table-2).

\section{Analysis of correlation between APPs and some bio-} chemical parameters

The correlation between APPs and biochemical parameters is presented in Table-3. A significant correlation was found between serum ceruloplasmin levels and $\mathrm{Hp}(\mathrm{r}=0.783, \mathrm{p}=0.001)$ and SAA levels $(\mathrm{r}=0.739, \mathrm{p}=0.001)$. A significant correlation was found between Hp, SAA, and ceruloplasmin levels and AST levels $(r=0.642, r=0.700$, and $r=0.697$, respectively) and ALP levels ( $\mathrm{r}=0.640, \mathrm{r}=0.615$, and $\mathrm{r}=0.643$, respectively) $(\mathrm{p}=0.001)$. Albumin levels correlated significantly only with serum AST level $(\mathrm{r}=0.205, \mathrm{p}=0.04)$. When the correlation between biochemical parameters was evaluated, a significant correlation was found between serum AST, ALP, urea, and creatinine levels. No significant correlation was found between TP levels and albumin $(\mathrm{r}=0.031$, $\mathrm{p}=0.76)$ and urea levels $(\mathrm{r}=0.061 ; \mathrm{p}=0.54)($ Table- 3$)$.

\section{Serum APP levels were compared according to body condition score and parity}

Cows were divided into two groups (BCS $\leq 2.75$ and $\mathrm{BCS}>2.75$ ) to determine the effects of BCS on APP levels. Hp, SAA, and ceruloplasmin levels in the group with BCS $\leq 2.75(153.25 \pm 8.40 \mu \mathrm{g} / \mathrm{ml}$, $23.23 \pm 1.05 \mu \mathrm{g} / \mathrm{ml}$, and $19.69 \pm 0.67 \mathrm{mg} / \mathrm{dl}$, respectively)

Table-2: The levels of some biochemical parameters in groups.

\begin{tabular}{|c|c|c|c|c|c|}
\hline Variables & Healthy $(n=30)$ & ME $(n=30)$ & $E(n=20)$ & SE $(n=20)$ & $\mathbf{p}$ \\
\hline \multicolumn{6}{|l|}{ AST (U/L) } \\
\hline$\overline{\mathrm{X}} \pm \mathrm{SEM}$ & $58.64^{\mathrm{a}} \pm 1.41$ & $65.82^{\mathrm{a}} \pm 2.02$ & $92.27^{b} \pm 5.40$ & $108.37^{`} \pm 3.52$ & $\begin{array}{c}\text { a:b: } 0.001 ; \\
\text { a:c: } 0.001 ; \\
\text { b:c: } 0.005\end{array}$ \\
\hline \multicolumn{6}{|l|}{$\operatorname{ALP}(U / L)$} \\
\hline$\overline{\mathrm{X}} \pm \mathrm{SEM}$ & $38.69^{\mathrm{a}} \pm 1.77$ & $45.27^{\mathrm{ab}} \pm 1.57$ & $52.98^{\mathrm{b}} \pm 1.69$ & $68.52^{c} \pm 3.49$ & $a: b: c: 0.001$ \\
\hline \multicolumn{6}{|c|}{ Urea $(\mathrm{mmol} / \mathrm{L})$} \\
\hline$\overline{\mathrm{X}} \pm \mathrm{SEM}$ & $7.62^{\mathrm{a}} \pm 0.17$ & $8.72^{\mathrm{b}} \pm 0.28$ & $9.04^{b c} \pm 0.33$ & $9.24^{\mathrm{bcd}} \pm 0.43$ & $\begin{array}{l}\text { a:b: } 0.02 \\
\text { a:bc: } 0.06 ; \\
\text { a:bcd: } 0.01\end{array}$ \\
\hline \multicolumn{6}{|c|}{ Creatinine $(\mu \mathrm{mol} / \mathrm{L})$} \\
\hline$\overline{\mathrm{X}} \pm \mathrm{SEM}$ & $82.36^{\mathrm{a}} \pm 2.07$ & $93.62^{\mathrm{b}} \pm 2.02$ & $138.44^{\mathrm{c}} \pm 4.14$ & $144.42^{\mathrm{cd}} \pm 5.13$ & $\begin{array}{r}\text { a:b: } 0.03 \\
\text { a:c: } 0.001 \\
\text { a:cd: } 0.001 \\
\text { b:c: } 0.001\end{array}$ \\
\hline \multicolumn{6}{|l|}{$\mathrm{TP}(\mathrm{g} / \mathrm{L})$} \\
\hline $\bar{X} \pm S E M$ & $67.77^{a} \pm 1.86$ & $68.91^{\mathrm{ac}} \pm 1.34$ & $72.45^{\mathrm{acb}} \pm 1.83$ & $76.25^{\mathrm{b}} \pm 2.45$ & $\begin{array}{l}\text { a:b: } 0.01 \\
\text { ac:b: } 0.03\end{array}$ \\
\hline
\end{tabular}

$\mathrm{n}=$ Number of cows, $\mathrm{AST}=$ Aspartate aminotransferase, $\mathrm{ALP}=$ Alkaline phosphatase, $\mathrm{TP}=$ Total protein, $\mathrm{ME}=\mathrm{Mild}$ endometritis, $\mathrm{E}=$ Moderate endometritis, $\mathrm{SE}=$ Severe endometritis, Differences between average values are shown by different letters $(a-c)$ on the same line $(\bar{X}=$ Mean value, $S E M=$ Standard error of the mean, $p=$ Value of statistical significance)

Table-3: Correlations between APPs and some biochemical parameters.

\begin{tabular}{lccccccccc}
\hline $\mathbf{n = 1 0 0}$ & Hp & SAA & Cp & Alb & AST & ALP & Urea & Crea & TP \\
\hline Hp & - & $0.723^{*}$ & $0.783^{*}$ & 0.062 & $0.642^{*}$ & $0.640^{*}$ & $0.343^{*}$ & $0.658^{*}$ & $0.297^{\S}$ \\
SAA & $0.723^{*}$ & - & $0.739 *$ & 0.157 & $0.700^{*}$ & $0.615^{*}$ & $0.323^{*}$ & $0.762^{*}$ & $0.277^{\S}$ \\
Cp & $0.783^{*}$ & $0.739 *$ & - & 0.141 & $0.697^{*}$ & $0.643^{*}$ & $0.399^{*}$ & $0.721^{*}$ & $0.299^{\S}$ \\
Alb & 0.062 & 0.157 & 0.141 & - & $0.205^{\S}$ & 0.146 & 0.086 & 0.197 & 0.031 \\
AST & $0.642^{*}$ & $0.700^{*}$ & $0.697^{*}$ & $0.205^{\S}$ & - & $0.585^{*}$ & $0.237^{*}$ & $0.692^{*}$ & $0.291^{\S}$ \\
ALP & $0.640^{*}$ & $0.615^{*}$ & $0.643^{*}$ & 0.146 & $0.585^{*}$ & - & $0.285^{\S}$ & $0.553^{*}$ & $0.209^{\S}$ \\
Urea & $0.343^{*}$ & $0.323^{*}$ & $0.399^{*}$ & 0.086 & $0.237 \S$ & $0.285^{\S}$ & - & $0.334^{*}$ & 0.061 \\
Crea & $0.658^{*}$ & $0.762^{*}$ & $0.721^{*}$ & 0.197 & $0.692^{*}$ & $0.553^{*}$ & $0.334^{*}$ & - & $0.279^{\S}$ \\
TP & $0.297^{\S}$ & $0.277^{\S}$ & $0.299^{\S}$ & 0.031 & $0.291^{\S}$ & $0.209^{\S}$ & 0.061 & $0.279^{\S}$ & - \\
\hline
\end{tabular}

$\mathrm{n}=$ Number of cows, Statistical significance of correlations: $* \mathrm{p}=0.001,{ }^{\&} \mathrm{p}=0.01,{ }^{\mathrm{s}} \mathrm{p}<0.05(\mathrm{Hp}=$ Haptoglobin $[\mu \mathrm{g} / \mathrm{ml}]$; $\mathrm{SAA}=$ Serum Amyloid $A(\mu \mathrm{g} / \mathrm{ml}), C p=$ Ceruloplasmin $(\mathrm{mg} / \mathrm{dl}), A \mathrm{lb}=$ Albumin $(\mathrm{g} / \mathrm{dl}), \mathrm{AST}=$ Aspartate aminotransferase $(\mathrm{U} / \mathrm{L})$, $A L P=A l k a l i n e ~ p h o s p h a t a s e ~(U / L)$, Urea $(\mathrm{mmol} / \mathrm{l})$, Crea=Creatinine $(\mu \mathrm{mol} / \mathrm{L}), T P=$ Total protein $(\mathrm{g} / \mathrm{L})$. APP=Acute phase protein 
were similar to the APP levels in the group with BCS $>2.75(148.21 \pm 10.78 \mu \mathrm{g} / \mathrm{ml}, 21.88 \pm 1.50 \mu \mathrm{g} / \mathrm{ml}$, and $19.32 \pm 1.12 \mathrm{mg} / \mathrm{dl}$, respectively), and no statistically significant difference was found $(\mathrm{p}>0.05)$. Hp $(143.04 \pm 9.45 \mu \mathrm{g} / \mathrm{ml})$, SAA $(23.17 \pm 1.35 \mu \mathrm{g} / \mathrm{ml})$, and ceruloplasmin $(19.15 \pm 0.76 \mathrm{mg} / \mathrm{dl})$ levels in primiparous cows were close to those in multiparous cows $(160.09 \pm 9.07 \mu \mathrm{g} / \mathrm{ml}, 22.81 \pm 1.16 \mu \mathrm{g} / \mathrm{ml}$, and $20.07 \pm 0.85 \mathrm{mg} / \mathrm{dl}$, respectively), and no statistically significant difference was found $(p>0.005)$ (Table-4).

\section{Discussion}

The aim of this study was to identify changes in serum ceruloplasmin levels in cows with endometritis based on the degree of severity and to establish whether or not serum ceruloplasmin levels can be used in the diagnosis of endometritis as an alternative to $\mathrm{Hp}$ and SAA levels. Many studies report that Hp, SAA, and APPs are reliable biomarkers in the diagnosis of uterine infections and facilitate monitoring of the treatment of endometritis [2,5,6,25-27]. Hp levels vary depending on the method of analysis, and the mean level reportedly ranges between 22 and $140 \mu \mathrm{g} / \mathrm{ml}$ in healthy animals $[2,26,28,29]$. Hp levels are reported to increase by 9 times if there is an infection [2,26,30]. SAA levels with a mean ranging between 16 and $22 \mu \mathrm{g} / \mathrm{ml}$ in healthy animals reportedly increase in the presence of uterine infections $(35-99 \mu \mathrm{g} / \mathrm{ml})[2,6,31]$. The levels of albumin, a negative APP, in cows with endometritis $(3.4 \pm 0.1 \mathrm{~g} / \mathrm{dl})$ were significantly lower than in healthy cows $(3.6 \pm 0.1 \mathrm{~g} / \mathrm{dl})$ [7]. Musal et al. [32], on the other hand, reported that albumin levels were higher in cows with endometritis $(3.34 \pm 0.12 \mathrm{~g} / \mathrm{dl})$ than in healthy cows $(3.17 \pm 0.15 \mathrm{~g} / \mathrm{dl})$. This study found that $\mathrm{Hp}$ and SAA levels were significantly higher in cows with endometritis and that they increase as endometritis becomes more severe. On the other hand, albumin levels in the groups were similar, and the presence and severity of endometritis had no significant effect on albumin levels.

Another indicator used in the assessment of animal health and welfare is ceruloplasmin [33]. It is recognized as a valuable source of information, particularly for detecting mastitis in cows $[34,35]$. Ceruloplasmin levels were higher in the milk of cows with subclinical mastitis $(3.35-8.02 \mathrm{U} / \mathrm{g})$ than in the milk of healthy cows $(0.72-2.11 \mathrm{U} / \mathrm{g})$ [35]. The serum ceruloplasmin level in clinically healthy cows in the postpartum period (week 3-5) was reported to be $22.1 \pm 5.89 \mathrm{mg} / \mathrm{dl}$ [36]. Another study found this level to be $0.163 \pm 0.011 \mathrm{U} / \mathrm{g}$ in healthy cows [37]. Lamand and Levieux [38] reported that plasma ceruloplasmin levels were higher in sheep with uterine infections or inflammation than in healthy sheep. In reviewing the literature, we did not find a study analyzing changes in the ceruloplasmin levels of cows diagnosed with endometritis of varying degrees of severity. This study found that serum ceruloplasmin levels were significantly higher in cows with endometritis than in healthy cows $(13.52 \pm 0.32 \mathrm{mg} / \mathrm{dl})$ and that the ceruloplasmin level significantly increases as endometritis becomes more severe. Ceruloplasmin increases various enzyme (cytochrome $\mathrm{C}$ oxidase and $\mathrm{Cu}-\mathrm{Zn}$ superoxide dismutase) activities together with copper, acts on immune system cells, and improves their phagocytosis and antimicrobial power. It also reduces the effects of oxygen radicals and protects cells against oxidative damage [11]. The increase in ceruloplasmin levels in cows with endometritis is thought to be caused by its effect on the immune system.

Body condition score, the most important indicator of the body's energy balance, is one of the most important factors playing a role in the change in the amount of oxidative stress. This is, therefore, reported to cause changes in ceruloplasmin levels [39]. However, this study failed to find an effect of BCS on APP concentrations. When groups based on BCS were compared, the BCS of most of the cows in the group with BCS $\leq 2.75$ was found to range between 2.50 and 2.75 and that of most of the cows in the group with BCS $>2.75$ were between 3 and 3.25. The fact that no statistically significant difference was found in APP levels is thought to be due to the fact that BCS was similar between the groups. There are also studies reporting that the number of parturitions changes APP levels. Metabolic changes arising from udder growth and development in primiparous cows after parturition are reportedly greater than in multiparous cows, and a higher amount of free oxygen radicals are generated. Ceruloplasmin levels are reported to be lower in primiparous cows than in multiparous cows because it is used as a buffering action against these radicals [39]. It has been reported that $\mathrm{Hp}$ levels are higher in primiparous cows in the week following parturition than in multiparous cows and that this is caused by the fact that damage to the uterus, vagina, and vulva may be

Table-4: Comparison of APP levels by BCS and parity ( $\overline{\mathrm{X}} \pm \mathrm{SEM})$.

\begin{tabular}{lcccc}
\hline Variables & Groups & Haptoglobin $(\boldsymbol{\mu g} / \mathbf{m l})$ & Serum amyloid A $(\boldsymbol{\mu g} / \mathbf{m l})$ & Ceruloplasmin $(\mathbf{m g} / \mathbf{d l})$ \\
\hline BCS & $\leq 2.75(n=72)$ & $153.25 \pm 8.40$ & $23.23 \pm 1.05$ & $19.69 \pm 0.67$ \\
& $>2.75(n=28)$ & $148.21 \pm 10.78$ & $21.88 \pm 1.50$ & $19.32 \pm 1.12$ \\
P & & 0.707 & 0.762 & 0.948 \\
Parity & Primiparous $(n=46)$ & $143.04 \pm 9.45$ & $23.17 \pm 1.35$ & $19.15 \pm 0.76$ \\
& Multiparous $(n=54)$ & $160.09 \pm 9.07$ & $22.81 \pm 1.16$ & $20.07 \pm 0.85$ \\
$P$ & & 0.969 & 0.280 & 0.442 \\
\hline
\end{tabular}

$\mathrm{n}=$ Number of cows, BCS=Body condition score, = Mean value, SEM=Standard error of the mean; $\mathrm{P}=$ Value of statistical significance, APP=Acute phase protein 
more severe during parturition [8]. However, this study showed that the number of parturitions had no significant effect on APP levels. The fact that the number of parturitions does not change APP levels suggests that uterine infections cause similar stress conditions in primiparous and multiparous cows.

Changes in biochemical components are blamed for reproductive failures. Therefore, evaluation of the biochemical profile is important to eliminate the problems caused by endometritis. Both serum urea concentrations and TP levels are reported to be higher in cows with endometritis than in healthy cows [40]. However, there are also studies reporting that endometritis does not change serum urea concentrations [17]. This study found that urea concentrations are higher in cows with endometritis and that they increase as endometritis becomes more severe. The elevated urea concentrations are reported have the effect of changing uterine $\mathrm{pH}$, weakening the local immune system, and increasing the severity of the infection [41]. This explains why the highest concentrations of urea are seen in the group with severe endometritis. A significant correlation is reported between urea concentrations and TP levels during the postpartum period (parturition-week 9 postpartum) [33]. Serum AST levels are reported to be higher in cows with endometritis than in healthy cows $[17,42]$. This study found that serum AST and ALP levels increase with endometritis, which is consistent with the aforementioned study. Tóthová et al. [33] found no correlation between urea concentrations and $\mathrm{Hp}, \mathrm{SAA}$, and albumin levels, but there was a significant correlation between creatinine levels and SAA, albumin, TP, and urea levels in a study they conducted. This study found significant correlations between all biochemical parameters except for TP both with each other and with APPs. As Burke et al. [17] reported that all these results show that endometritis impairs liver functions (as a result of toxins produced during infection indirectly reaching the liver).

\section{Conclusion}

It was determined that endometritis changes both APP levels and biochemical parameters. Serum ceruloplasmin levels in cows with endometritis which were not known before were significantly higher in the presence of endometritis, and the severity of endometritis plays an important role in this increase. A significant correlation was found between serum ceruloplasmin levels and $\mathrm{Hp}$ and SAA levels. It was concluded that ceruloplasmin levels can be used in the diagnosis of endometritis as an alternative to Hp and SAA levels. Routine laboratory analyses of APPs can help reduce financial losses significantly by facilitating early diagnosis of diseases affecting reproduction, such as endometritis and monitoring treatment efficacy.

\section{Authors' Contributions}

This work was carried out in collaboration between all authors. SK, CK and AC: Designed the experimental procedures. SK and CK: Conducted the research work. OM: Helped in laboratory analysis. SK, AC, KB: Prepared figures, tables, revised and submitted the manuscript. All authors read and approved the final manuscript.

\section{Acknowledgments}

The authors are thankful to the I. Safa Gurcan, for the help of statistical analysis of this study. The authors are grateful to the directors of both farms in Kafkas University Veterinary School Research and Application Farm for help gain access to the facilities to carry out the investigations.

\section{Competing Interests}

The authors declare that they have no competing interests.

\section{References}

1. Cray, C., Zaias, J. and Altman, N.H. (2009) Acute phase response in animals: A review. Comp. Med., 59: 517-526.

2. Biswal, S.S., Das, S., Balasubramanian, S., Mohanty, D.N., Sethy, K. and Dasgupta, M. (2014) Serum amyloid A and haptoglobin levels in crossbred cows with endometritis following different therapy. Vet. World, 7: 1066-1070.

3. Tothova, C., Nagy, O. and Kovac, G. (2011) Acute phase proteins and their use in the diagnosis of diseases in ruminants: A review. Vet. Med. Czech., 59: 163-180.

4. Thomas, F.C., Waterston, M., Hastie, P., Parkin, T., Haining, H. and Eckersall, P.D. (2015) The major acute phase proteins of bovine milk in a commercial dairy herd. BMC Vet. Res., 11: 207.

5. Brodzki, P., Kostro, K., Brodzki, A., Wawron, W., Marczuk, J. and Kurek, Ł. (2015) Inflammatory cytokines and acute-phase proteins concentrations in the peripheral blood and uterus of cows that developed endometritis during early postpartum. Theriogenology, 84: 11-18.

6. Chan, J.P.W., Chu, C.C., Fung, H.P., Chuang, S.T., Lin, Y.C., Chu, R.M. and Lee, S.L. (2004) Serum haptoglobin concentration in cattle. J. Vet. Med. Sci., 66: 43-46.

7. Green, M.P., Ledgard, A.M., Berg, M.C., Peterson, A.J. and Back, P.J. (2009) Prevalence and identification of systemic markers of sub-clinical endometritis in postpartum dairy cows. Proc. N. Z. Soc. Anim., 69: 37-42.

8. Humblet, M.F., Guyot, H., Boudry, B., Mbayahi, F., Hanzen, C., Rollin, F. and Godeau, J.M. (2006) Relationship between haptoglobin, serum amyloid $\mathrm{A}$, and clinical status in a survey of dairy herds during a 6-month period. Vet. Clin. Pathol., 35: 188-193.

9. Floris, G., Medda, R., Padiglia, A. and Musci, G. (2000) The physiopathological significance of ceruloplasmin. Biochem. Pharmacol., 60: 1735-1741.

10. Lóvstad, R.A. (2006) A kinetic study on the phenothiazine dependent oxidation of NADH by bovine ceruloplasmin. BioMetals, 19: 1-5.

11. Cerone, S.I., Sansinanea, A.S., Streitenberger, S.A., Garcia, M.C. and Auza, N.J. (2000) Cytochrome c oxidase, $\mathrm{Cu}, \mathrm{Zn}$-superoxide dismutase, and ceruloplasmin activities in Copper-deficient bovines. Biol. Trace. Elem. Res., 73: 269-278.

12. Banuvalli, N., Bhaskaran, R., Krishnamurthy, U., Gruraj, P.M., Kumar, K.P.H. and Rames, H.S. (2014) Effect of body condition score at parturition on post-partum productive and reproductive performance in crossbred dairy cows. Int. J. Livest. Res., 4: 5-13.

13. Weber, C., Hametner, C., Tucscherer, A., Losand, B., Kanitz, E., Otten, W., Singh, S.P., Bruckmaier, R.M., Becker, F., Kanitz, W. and Hammon, H.M. (2013) Variation 
in fat mobilization during early lactation differently affects feed intake, body condition, and lipid and glucose methabolism in high-yielding dairy cows. J. Dairy Sci., 96: 165-180.

14. Gong, J.G., Lee, W.J., Garnworthy, P.C. and Webb, R. (2002) Effect of dietary-induced increases in circulating insulin concentrations during the early postpartum period on reproductive function in dairy cows. Reproduction, 123: 419-427.

15. Liu, P., He, B.X., Yang, X.L., Hou, X.L., Zhao, H.Y., Han, Y.H., Nie, P., Deng, H.F. and Cheng, L. (2012) Activities of aspartate aminotransferase, alanine aminotransferase, gamma-glutamyl transferase, alkaline phosphatase in plasma of postpartum Holstein cows. J. Anim. Vet. $A d v$., 11: 1270-1274.

16. Đoković, R., Šamanc, H., Petrović, M.D., Ilić, Z. and Kurćibić, Z. (2012) Relationship among blood metabolites and lipid content in the liver in transitional dairy cows. Biotechnol. Anim. Husb., 28: 705-714.

17. Burke, C.R., Meier, S., Mcdougall, S., Compton, C., Mitchell, M. and Roche, J.R. (2010) Relationships between endometritis and metabolic state during the transition period in pasture-grazed dairy cows. J. Dairy Sci., 93: 5363-5373.

18. Williams, E.J., Fischer, D.P., Pfeiffer, D.U., England, G.C.W., Noakes, D.E., Dobson, H. and Sheldon, I.M. (2005) Clinical evaluation of postpartum vaginal mucus reflects uterine bacterial infection and the immune response in cattle. Theriogenology, 63: 102-117.

19. Kasimanickam, R., Duffield, T.F., Foster, R.A., Gartley, C.J., Leslie, K.E., Walton, J.S. and Johnson, W.H. (2004) Endometrial cytology and ultrasonography for the detection of subclinical endometritis in postpartum dairy cows. Theriogenology, 62: 9-23.

20. Mari, G., Iacono, E., Toni, F., Predieri, P.G. and Merlo, B. (2012) Evaluation of the effectiveness of intrauterine treatment with formosulphathiazole of clinical endometritis in postpartum dairy cows. Theriogenology, 78: 189-200.

21. Edmonson, A.J., Lean, I.J., Weaver, L.D., Farver, T. and Webster, G. (1989) A body condition score chart for Holstein dairy cows. J. Dairy Sci., 72: 68-78.

22. Skinner, J.G., Brown, R.A. and Roberts, L. (1991) Bovine haptoglobin response in clinically defined field conditions. Vet. Rec., 128: 147-149.

23. Colombo, J.P. and Richterich, R. (1964) On the determination of ceruloplasmin in plasma. Schweiz. Med. Wochenschr., 94: 715-720.

24. Gardner, I.A. and Greiner, M. (2006) Receiver-operating characteristic curves and likelihood ratios: Improvements over traditional methods for evaluation and application of veterinary clinical pathology tests. Vet. Clin. Pathol., 35: 8-17.

25. Biswal, S.S.H., Das, S. and Mohanty, D.N. (2013) Immunomodulatory effect of oyster glycogen on endometritic crossbred cows. Indian J. Anim. Reprod., 34: 21-24.

26. Chan, J.P.W., Chang, C.C., Hsu, W.L., Liu, W.B. and Chen, T.H. (2010) Association of increased serum acutephase protein concentrations with reproductive performance in dairy cows with postpartum metritis. Vet. Clin. Pathol., 39: 72-78.

27. Dubuc, J., Duffield, T.F., Leslie, K.E., Walton, J.S. and Leblanc, S.J. (2010) Risk factors for postpartum uterine diseases in dairy cows. J. Dairy Sci., 93: 5764-5771.

28. Alberghina, D., Piccione, G., Casella, S., Panzera, M.,
Morgante, M. and Gianesella, M. (2013) The effect of the season on some blood metabolites and haptoglobin in dairy cows during postpartum period. Arch. Tierzucht., 56: 354-359.

29. Khoshvaghti, A., Nazifi, S., Vafafar, A. and Gheisari, H.R. (2009) Evaluation of serum and milk haptoglobin in some inflammatory diseases of cattle. Int. J. Vet. Res., 3: 31-36.

30. Hassanpour, A., Gholipour, M. and Rezaie, A. (2011) The effect of using monensin on haptoglobin serum level in dairy cattle. J. Anim. Vet. Adv., 10: 1364-1367.

31. Jeremejeva, J., Orro, T. and Kask, K. (2015) Relationship between acute phase proteins and subsequent fertility of dairy cows after postpartum uterine inflammation and healthy cows. Vet. Med. Zoot., 70: 37-41.

32. Musal, B., Seyrek, K. and Ulutaş, P.A. (2004) Serum sialic acid, total protein and albumin levels in cows with metritis treated with intrauterine oxytetracycline. Uludağ Univ. J. Fac. Vet. Med., 23: 71-75.

33. Tóthová, C.S., Nagy, O., Seidel, H., Konvićná, J., Farkašová, Z. and Kovác, G. (2008) Acute phase proteins and variables of protein metabolism in dairy cows during the pre - and postpartal period. Acta Vet. Brno., 77: 51-57.

34. Chassagne, M., Barnouin, J. and Chacornac, J.P. (1998) Biological predictors for early clinical mastitis occurrence in Holstein cows under field conditions in France. Prev. Vet. Med., 35: 29-38.

35. Szczubiał, M., Dąbrowski, R., Kankofer, M., Bonchniarz, M. and Komar, M. (2012) Concentration of serum amyloid A and ceruloplasmin activity in milk from cows with subclinical mastitis caused by different pathogens. Pol. J. Vet. Sci., 15: 291-296.

36. Hussein, H.A. and Staufenbiel, R. (2012) Variations in copper concentration and ceruloplasmin activity of dairy cows in relation to lactation stages with regard to ceruloplasmin to copper ratios. Biol. Trace Elem. Res., 146: 47-52.

37. Kankofer, M., Albera, E., Feldman, M., Gundling, N. and Hoedemaker, M. (2010) Comparison of antioxidative/ oxidative profiles in blood plasma of cows with and without retained fetal placental membranes. Theriogenology, 74: 1385-1395.

38. Lamand, M. and Levieux, D. (1981) Effects of infection on plasma levels of copper and zinc in ewes. Ann. Rech. Vét., 12: 133-136.

39. Talukder, S., Kerrisk, K.L., Gabai, G., Fukutomi, A. and Celi, P. (2015) Changes in milk oxidative stress biomarkers in lactating dairy cows with ovulatory and an-ovulatory oestrous cycles. Anim. Reprod. Sci., 158: 86-95.

40. Ahmad, I., Lodhi, L.A., Qureshi, Z.I. and Younis, M. (2004) Studies on blood glucose, total proteins, urea and cholesterol levels in cyclic, non-cyclic and endometritic crossbred cows. Pak. Vet. J., 24: 92-94.

41. Kaufmann, T.B., Drillich, M., Tenhagen, B.A. and Heuwieser, W. (2010) Correlations between periparturient serum concentrations of non-esterified fatty acids, betahydroxybutyric acid, bilirubin, and urea and the occurrence of clinical and subclinical postpartum bovine endometritis. BMC. Vet. Res., 6: 1-6.

42. Heidarpour, M., Mohri, M., Fallah-Rad, A.H., Shahreza, F.D. and Mohammadi, M. (2012) Acute phase protein concentration and metabolic status affect the outcome of treatment in cows with clinical and subclinical endometritis. Vet. Rec., 171: 219 . 